\title{
Romėniška moneta iš Panemunės pilies
}

\author{
ARVYDAS MALONAITIS \\ Lietuvos edukologijos universitetas, T. Ševčenkos g. 31, LT-03111 Vilnius \\ El. paštas arvydas.malonaitis@leu.It
}

\begin{abstract}
Straipsnyje apžvelgiama $2011 \mathrm{~m}$. archeologinių tyrinèjimų metu Panemunès pilies (Jurbarko r. sav., Pilies I k., Skirsnemunès sen.) kieme rasta romeniška Gordiano III (valdè 238-244 m.) moneta. Daroma prielaida, kad moneta ị pili galëjo patekti kaip kolekcijos dalis arba iš netoliese pažeisto senojo geležies amžiaus objekto (kapo ar gyvenvietės) ir kartu su žvyru atsidurti tarp statybinių atliekų. Straipsnyje pateikiamos monetos radimo situacijos, jos iliustracijos.
\end{abstract}

Raktažodžiai: Panemunès pilis, Gordiano III moneta, antoninianas

\section{IVADAS}

2011 m. atliekant archeologinius tyrinèjimus Panemunès pilies (Jurbarko r. sav., Pilies I k., Skirsnemunės sen.) kieme rasta romėniška Gordiano III (valde 238-244 m.) moneta. Apie monetą buvo paskelbta pirminė informacija, pateikta jos iliustracija [11, 186-199, pav. 9]. Tai turbūt pirmas kartas, kai toks radinys buvo aptiktas pilies teritorijoje. Iprasta, kad romėniškų monetų randama kapuose, ypač Vakarų Lietuvoje, lobiuose, rečiau gyvenvietėse. $2001 \mathrm{~m}$. duomenimis, iš 101 vietovès, kuriose rasta romėniškų monetų, 34 buvo kapinynai, 19 - lobių, 10 - piliakalnių ir gyvenviečių [14]. Kitais atvejais radavietès rūšis neaiški. Visgi galima daryti prielaidą, kad ir tarp šių atvejų didžiąją dalị sudaro monetos iš kapinynų, tik apie tai dar trūksta duomenų. Nors romėniškos monetos nėra itin retas radinys - jų rasta daugelyje Lietuvos vietovių, vis dèlto jų randama ne kasdien. Todèl kiekvienas naujas radinys yra svarbus mūsų praeičiai pažinti ir nusipelno atidesnio žvilgsnio.

Žvelgiant ị pilies tyrinėjimų metu surinktą medžiagą matyti, kad Gordiano III moneta nelabai dera prie pilies gyvavimo tarpsnio ir vẻlesnio laikotarpio radinių. Ji čia iškyla kaip atsitiktinis ar net pašalinis radinys. Nepaisant to, būtina detaliau aptarti monetos radimo aplinkybes ir galimus jos patekimo ị pilị būdus.

Taigi straipsnio tikslas - paskelbti Panemunès pilyje rastą Gordiano III monetą, aptarti jos radimo aplinkybes, ịvertinti jos vietą tarp visų šio valdovo monetų, rastų Lietuvoje.

Straipsnyje vartojamas pavadinimas Panemunes pilis, nes tokiu pavadinimu objektas yra i̇registruotas Nekilnojamųjų kultūros paveldo vertybių registre, taip jị vadina vietiniai gyventojai ir turistai, toks pavadinimas įsigali komercinèse struktūrose. Esamų statinių mastai 
taip pat labiau asocijuojasi su pilimi. Visgi vardan tikslumo verta priminti, kad objektą derètų vadinti ne pilimi, o dvaru $[5,133]$.

\section{MONETOS RADIMO APLINKYBĖS}

Romėniškos monetos radimas susijęs su antruoju $2011 \mathrm{~m}$. vykusių tyrinejjimų etapu Panemunejje [11, 187, pav. 1]. Jo metu tyrinejjimai vyko pilies kieme, jau pirmame etape ištirtų būsimų nuotekynų vietose. Ištyrus visą kiemo kultūrinį sluoksnį paaiškẻjo, jog dalis pirminio kiemo paviršiaus atrode kitaip, nei dabar matome. Pradžioje čia būta pailgos kalvos su paviršiuje esančiu žvyru, smèliu ir moliu, o arčiau dabartinès pietinio ir vakarinio korpusų sandūros - vandeningomis gyslomis. Kalva buvo nežymiai nuolaidi ị rytinę ir šiaurinę puses. Dalis kalvos turèjo didesnį nuolydị pietų pusén. Dabar tai atitiktų apie $10 \mathrm{~m}$ pločio ruožą prie pietinio korpuso nuo pirmo įejimo (skaičiuojant nuo pietinio ir vakarinio korpusų sandūros) iki pat rytinio korpuso.

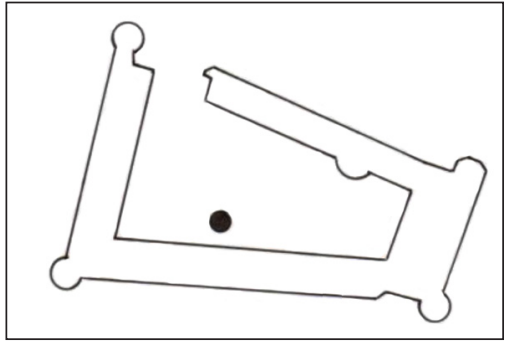

1 pav. Bendroji monetos radimo situacija (A. Malonaičio brèžinys) Ši aplinkybė buvo išnaudota praktiškai - bent jau daliai pietinio korpuso pamatų nereikejo kasti gilių tranšejųu. Statybos ir rekonstrukcijų metu iš įvairių statybinių atliekų ir duženų susikloste iki $1 \mathrm{~m}$ storio sluoksnis ir loma niveliavosi. Vẻlesni ịvairūs perkasimai paviršiaus formos iš esmès nepakeitè, ir ruožas prie pietinio korpuso pakraščio prieš tyrinejjimus atrodè daugiau ar mažiau lygus.

Kaip matyti 1 paveiksle, moneta rasta arčiau pietinio korpuso, apie 5,5 m i šiaurę nuo jo sienos ir šiek tiek arčiau vakarinio korpuso. Bendrame tyrinejjimų plane tai atitinka 41 perkasą (13-oji antro etapo perkasa). Visame perkasos plote po paviršiniu velènos ir įvairiu užžertu sluoksniu su $\mathrm{XX}$ a. pabaigos atributais (vinys, spygliuota viela, dviračio detalès ir pan.) atidengtas 30$40 \mathrm{~cm}$ storio tamsus sluoksnis su plytų, koklių, stiklo duženomis, puodų šukėmis, kaulais. Perkasos pietiniame pakraštyje, apie $30 \mathrm{~cm}$ gylyje, atsidenge $2 \times 0,45 \mathrm{~m}$ dydžio grindinio fragmentas, sudarytas iš įvairaus dydžio akmenų. Po grindiniu rastas ganètinai storas plytų duženų ir kalkių skiedinio sluoksnis, vietomis su nedidelėmis tuštumomis, plonejjantis link šiaurinès perkasos pusès. Jame taip pat pasitaikè pavieniai koklių ir puodų fragmentai. Būtent šio sluoksnio pakraštyje, kv. 3B, apie $70 \mathrm{~cm}$ gylyje, ir buvo rasta Gordiano III moneta. Tos pačios perkasos kv. 1C, beveik $85 \mathrm{~cm}$ gylyje, tarp plytų duženų ir kiek šviesesnio skiedinio rastas apnykęs Rygoje kaldintas Zigmanto III Vazos šilingas. Kadangi didesnè jo dalis pasidengusi žalia patina, tiksli kaldinimo data neisskaitoma. Iš viso perkasoje rasta per 50 puodų šukių, 60 koklių fragmentų, daugiausia XVII-XVIII a., 7 kaltinès vinys, raktas, durų sklendès svirtis. Be to, perkasoje atidengtos trys antžeminės konstrukcijos tvirtinimo dalys - i įžemị igręžtų stulpų fragmentai su armatūra. Tai pilies konservavimo ir restauravimo darbų, vykusių XX a. 7-8 dešimtmečiais, liekanos.

\section{MONETOS CHARAKTERISTIKA}

Kaip matyti iš 2 paveikslèlyje ir 1 lentelejje pateiktų duomenų, aptariama moneta priklauso vadinamiesiems antoninianams, cirkuliavusiems III amžiuje. Monetos pradètos kaldinti $215 \mathrm{~m}$. Karakalos iqsakymu ir buvo skirtos piniginei apyvartai suvaldyti. Vèlyvajame savo gyvavimo etape moneta virto bronzine ar varine, iš viršaus padengta sidabru, bet jos kursas 


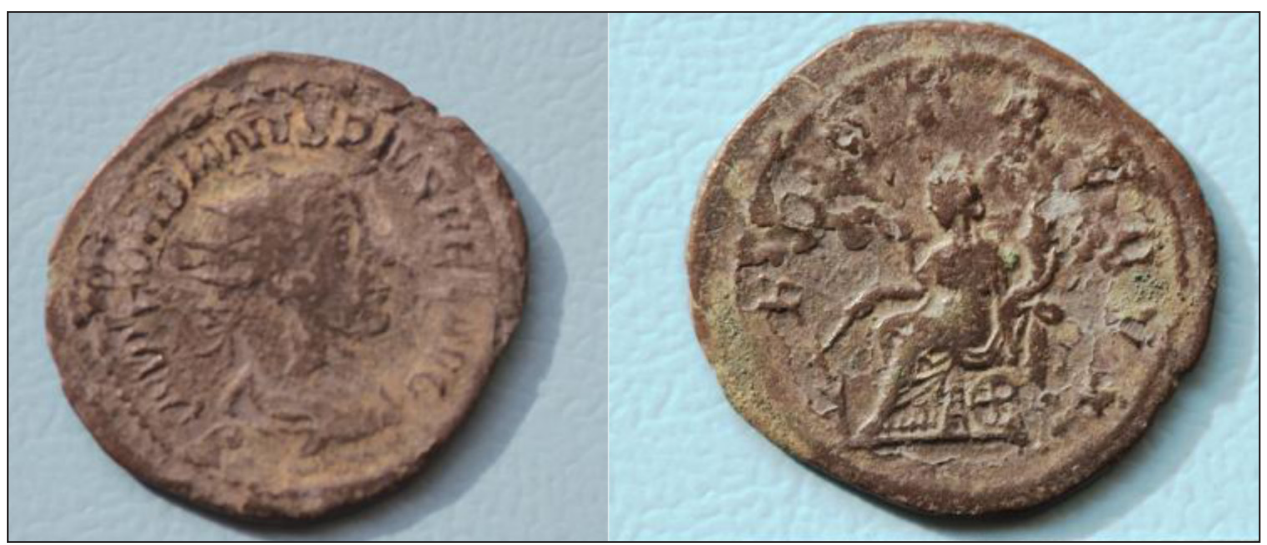

2 pav. Gordiano III (238-244 m.) moneta. Aversas ir reversas (A. Malonaičio nuotr.)

buvo palaikomas dirbtinai. Svarbiausias išorinis monetos požymis, pagal kurị ji lengvai atpažistama, - ne su lauro vainiku, bet su spinduline karūna pavaizduotas imperatorius.

Turima moneta Romos imperijos monetų kataloge (RIC) atitinka Nr. 143. Charakteringas bruožas - sėdinti deivė Fortūna ir sutrumpintas jos vardo įrašas FORT. Tokios monetos priklauso vèlyvajai 5-ajai emisijai (243 m. ruduo - $244 \mathrm{~m}$. vasara) ir buvo kaldinamos Romoje $[12,7,11-12,31](1)$.

\section{1 lentelè. Pagrindiniai monetos duomenys}

\begin{tabular}{|c|c|}
\hline Nominalas & Antoninianas \\
\hline Kalimo laikas & 243-244 m. \\
\hline Kalimo vieta & Roma \\
\hline Monetos tipas & Cirkuliuojanti (apyvartinè) moneta \\
\hline Proga / skirta & $\begin{array}{c}\text { I dešinę pasisukusio imperatoriaus Gordiano III biustas. } \\
\text { Aversas }\end{array}$ \\
\hline Ant galvos - spindulinè karūna, ant kaklo ir krūtinès - drapiruotė; \\
aplinkui - užrašas IMP GORDIANVS PIVS FEL AVG.
\end{tabular}

(1) Už konsultacijas nuoširdžiai dèkoju prof. habil. dr. Mykolui Michelbertui. 
Gordiano III (Marcus Antonius Gordianus Pius III, 225-244 m.) valdymo laikotarpis (238-244 m.) priskiriamas vadinamojo politinio chaoso periodui, prasidejusiam nuvertus Severų dinastiją. Nužudžius keletą mėnesių kartu valdžiusius Balbiną ir Pupieną, pretorionų gvardija 13 metų berniuką paskelbè imperatoriumi ir suteiké Augusto titulą (kaip ipédinis Cezario titulą jis turejjo jau anksčiau). Jaunam valdovui talkino Timesitèjas, vèliau tapęs pretoriumi-prefektu ir paskirtas rūpintis sienų apsauga Artimuosiuose Rytuose. Po jo mirties pareigas perèmęs Julijus Pilypas Arabas turèjo rimtų ketinimų pats tapti valdovu. 244 m. per karinę operaciją Mesopotamijoje Gordianas III buvo nužudytas.

Iš viso turèjo šešis titulus: CAESAR; AVGVSTVS; PM (Pontifex Maximus); PP (Pater Patria); PIVS; FELIX, kurie būdavo iškalti monetų legendose:

M ANT GORDIANVS CAES;

IMP CAES GORDIANVS PIVS AVG;

IMP CAES M ANT GORDIANVS PIVS AVG;

IMP C M ANT GORDIANVS AVG;

IMP GORDIANVS PIVS FEL(IX) AVG.

Sidabriniai ir biloniniai antoninianai bei sestercijai Gordiano III valdymo metu buvo iprastos monetos. Vidutinès bronzinès monetos ir denarai pasitaikydavo rečiau. Pažymètini labai reti medalionai ir didelès bronzinès monetos su pergalès simboliais bei vadinamosios provincijos monetos, tarp kurių būta tokių, kuriose valdovas pavaizduotas su savo žmona Trankvilina. Pats valdovo portretas monetose vaizduojamas labai įvairiai [7, 265-270].

Roméniškos monetos ir kiti daiktai tiek Lietuvoje, tiek ir visame Rytų Baltijos regione paprastai siejami su prekybiniu Gintaro keliu. Pradetas eksploatuoti dar akmens amžiuje, gintaras, pasak tyrèjų, neolito pabaigoje padejjo iškilti ryškiai Pamarių kultūrai [4, 224-226]. Nuo to laiko ne kartą buvo fiksuojamas gintaro prekybos suaktyvejjimas, tačiau didžiausią mastą prekyba igavo Romos imperijos laikais, kai susiformavo sudètingas prekybinis darinys - Gintaro kelias ir prekybos mastai buvo didžiausi. Pirmiausia juo ị imperijos gilumą keliavo gintaro žaliava. Be to, romėnams rūpejjo kailiai, oda, medus, vaškas ir greičiausiai vergai. I aisčių žemes buvo gabenami romėniški daiktai, papuošalai, monetos. Tyrimai rodo, kad tai nebuvo vien paprasti mainai - tikriausiai veikè daugiau ar mažiau susiformavusios atitinkamos organizatorių, tarpininkų, vykdytojų, užsakovų ir pan. struktūros, t. y. visa tai, ką šiuolaikiniais terminais galima apibūdinti kaip infrastruktūrą. Panašu, kad tuo metu nuolatinès prekyvietės-faktorijos prekiaudavo ne tik su pajūrio, bet ir toliau nuo jūros gyvenusiais aisčiais [6, 113-115; 4:10 il.]. Tyrejai pažymi, kad tai buvo bene svarbiausias veiksnys, lemęs aisčių kraštų praturtėjimą, paskatinusį kultūros kaitą ir migracijas, vietinio prekybinio elito susiformavimą, tad monetos kapuose vertintinos kaip tam tikras šio elito atributas $[6,118]$. Dažnai pažymima, kad monetos buvo atsiskaitymo priemonè, tačiau akivaizdu, kad tai nèra vienintelè jų naudojimo sritis. Jos galèjo būti kaupiamos ir panaudojamos kaip duoklè, išpirka, kraitis, apsikeitimui kaip prestižinėmis dovanomis. Kaip savitą monetų paskirtị baltų gentyse galima vertinti jų dejjimą ị kapus [3, 434].

Prekybinio kelio gyvavimo laikotarpis nebuvo vienalytis ir tą bene ryškiausiai atspindi monetos. Jų pasiskirstymo kapuose Rytų Baltijos regione nuo Vyslos iki Gaujos analizė rodo, kad daugiausia monetų yra iš Nervos-Antoninų dinastijų valdymo laikotarpio (96-191 m.), ypač iš 151-170 m. tarpsnio [6, 98; 4:5; 4:6 il.]. Ko gero, tai atspindi didžiausią prekybos mastą. Vèliau prekyba ir monetų srautas ėmé mažèti ir trumpam atsigavo tik Aleksandro Severo (222-235 m.) ir vadinamųjų vėlyvųjų imperatorių - Maksimino I (235-238 m.), Gordiano III (238-244 m.) ir Pilypo Arabo (244-249 m.) - valdymo laikais [6, 98; 4:5 il.]. Iš 
pastarųjų trijų imperatorių kapuose daugiausia randama Gordiano III monetų. Iš viso minètame regione $2014 \mathrm{~m}$. buvo žinomi 29 egz. [ 6, 100; 4:5 il.]. Turimos monetos yra nevienodai išlikę. Kartais sunku ar iš viso neįmanoma nustatyti, kokio imperatoriaus laikais jos kaldintos, todèl tikètina, kad tarp neatpažintų gali pasitaikyti viena kita Gordiano III moneta.

2 lentelè. Lietuvoje rastos Gordiano III monetos (2001 m. duomenys, papildyti straipsnio autoriaus)

\begin{tabular}{|c|c|c|c|c|}
\hline Eil. Nr. & Vietovè & Radinio rūšis & Nominalas & Medžiaga \\
\hline 1 & Aukštkiemiai & k. 219 & $?$ & $\mathrm{AEI}^{*}$ \\
\hline 2 & Aukštkiemiai & k. 330 & $?$ & AEI \\
\hline 3 & Aukštkiemiai & atsitiktinis kapinyne & $?$ & AEI \\
\hline 4 & Bandužiai & k. 59 & sestercijus & $?$ \\
\hline 5 & Bandužiai & atsitiktinis kapinyne & sestercijus & $?$ \\
\hline 6 & Dargiškè & lobis & ? graikiškas įrašas & $A E^{* *}$ \\
\hline 7 & Dauglaukis & k. 127 & sestercijus & $?$ \\
\hline 8 & Garliava & nežinoma & $?$ & $\mathrm{AE}$ \\
\hline 9 & Janapolè & lobis, 7 egz. & $\begin{array}{c}\text { antoninianai, visi su } \\
\text { graikiškais įrašais }\end{array}$ & bilonas \\
\hline 10 & Klaipèdos apskr. & nežinoma & sestercijus & $?$ \\
\hline 11 & Kvèdarna & piliakalnis & sestercijus & $?$ \\
\hline 12 & Lazdininkai? & k. 201 & sestercijus & $?$ \\
\hline 13 & Noruišiai & iš suardytų kapu & ? graikiškas įrašas & $\mathrm{AE}$ \\
\hline 14 & Palanga & k. 14 & sestercijus & $?$ \\
\hline 15 & Palanga & iš suardytų kapu & $?$ & $\mathrm{AEII}^{* * * *}$ \\
\hline 16 & Panemunè & $\begin{array}{c}\text { XVII-XVIII a. statybinių } \\
\text { atliekų sluoksnyje }\end{array}$ & antoninianas & varis? \\
\hline 17 & Skèriai & kapinyne & $?$ & AEI? \\
\hline 18 & Stragnai & iš suardyto kapo & sestercijus & $?$ \\
\hline 19 & Stragnai & iš suardyto kapo & sestercijus & $?$ \\
\hline 20 & Šernai & k. 67 & $?$ & AEI \\
\hline 21 & Šernai & k. 110 & $?$ & $\mathrm{AEI}$ \\
\hline 22 & Šernai & nežinoma & $?$ & $A E ?$ \\
\hline 23 & Veliuona & lobis & antoninianas & sidabras? \\
\hline
\end{tabular}

*Varinès, bronzinès monetos, nominalas nežinomas,

** didelès bronzinès monetos, nominalas nežinomas,

*** vidutinès bronzinès monetos, nominalas nežinomas [14, 25].

Kaip matyti iš 2 lentelès, Lietuvoje iš viso buvo žinoma 16 vietovių, kuriose rastos 29 Gordiano III monetos. Daugiausia jų aptikta kapinynuose ( 9 vietovès, 15 monetų), mažiau - lobiuose (3 lobiai, 9 monetos), viena rasta piliakalnyje, trimis atvejais neaišku, kokiuose paminkluose jos buvo rastos [14], viena rasta XVII-XVIII a. statybinių atliekų sluoksnyje. Lietuvos teritorijoje rastos Gordiano III monetos skiriasi nominalu, medžiaga, kaldinimo vieta ir laiku, reverse vaizduojama dievybe. Bene didžiausią jų dalị sudaro vadinamosios provincijos monetos su graikiškais užrašais - iš viso 9 egz. Iš jų net 7 egz. 
rasti Janapolès lobyje kartu su Aleksandro Severo (222-235 m.), Julijos Mamejos (mirusi 235 m.), Maksimino I (235-238 m.) ir Maksimo (235-238 m.) monetomis [17, 68-70; табл. $1 ; 13$, 55; 17 pav.]. Po vieną tokią monetą rasta Dargiškès lobyje [17, 70; рис. 1] ir suardytuose Noruišių pilkapiuose.

\section{GALIMI PATEKIM0 | PIL̨ BŪDAI}

Kaip aptariama moneta galëjo patekti ị statybinių atliekų sluoksnius? Labai paprastai - lygiai taip pat, kaip apskritai monetos patenka ị kultūrinius sluoksnius. Kartais iš tiesų sunku paaiškinti, kaip panašūs objektai atsiduria neịtikètinose vietose. Pavyzdys - vadinamoji „kalkių duobë“ perkasų Nr. 33 ir Nr. 35 sandūroje. Dar neseniai tai būdavo ịprastas statybų aikštelių ịrenginys, kuriame gesintos kalkès ir jų pagrindu ruoštas skiedinys. Dažniausia tai - įvairaus gylio stačiakampè duobė su neaukštu lentų rentiniu viršuje.

Tyrinejjimų metu atidengtos duobès paviršiuje esančios šiukšlès ir daiktai bei nesunykusios lentos rodo, jog šis objektas atsirado po $1961 \mathrm{~m}$. tyrinejjimų èmus tvarkyti pilị. Preparuojant duobès turinį, maždaug 40-50 cm gylyje vienalyteje skiedinio masejje rastas labai apnykęs Prūsijos valdovo Frydricho II grašis (176? m.). Pagilinus dar apie $40 \mathrm{~cm}$, taip pat vienalytejje terpeje rasta Gelgaudiškio plytų gamykloje pagaminta plyta su ịspausta 1956 m. data. Toliau jokių radinių nebuvo iki pat dugno 1,5-1,7 m gylyje, kur rasta ir ịvairių pilies gyvavimo laikotarpių, ir šiuolaikinių daiktų, patekusių kaip šiukšlès. Plytos atsiradimas kalkių duobejje suprantamas - kažkas ją paprasčiausiai įmetė. Greičiausiai lygiai taip pat buvo pasielgta ir su moneta. Gal ji buvo palaikyta neaiškiu ir nereikšmingu menkniekiu, nors turejjo atrodyti kur kas gražiau nei pabuvojusi kalkių skiedinio terpeje.

Grynai teoriškai galima manyti, kad kažkas, lankydamasis pietinio korpuso statybvietejje, Gordiano III monetą tiesiog pametè. Moneta galejjo iškristi nepastebimai arba išsprūsti iš rankų. Taip galèjo būti, nes dažniausia tokiu būdu monetos patenka ị kultūrinius sluoksnius. Čia ịdomu būtų kitkas - kaip ir iš kur pas tariamą asmenį galèjo atsirasti tokia moneta ir kas buvo tas asmuo. XVI-XVIII a. yra pirmųjų kolekcijų mūsų krašte laikas. Pirmiausia jos atsirado turtingų ir įtakingų asmenų dvaruose, tačiau jas tuo metu ir véliau kaupé pavieniai kunigai bei ịvairūs šviesuoliai. Nors šis kultūrinių vertybių kaupimo laikotarpis Lietuvoje iki šiol nèra išsamiau nagrinètas, bet apie įvairius rinkinius ir juose buvusius daiktus įvairiomis progomis užsimenama gana dažnai $[8,19 ; 9,15-21 ; 108-110]$. Bene daugiausia dèmesio iki šiol yra sulaukusios Radvilų giminės kolekcijos [8, 23-29]. Kadangi dvarų prestižas buvo vertinamas ne vien pagal priemimų prabangą, bet ir pagal turimus įvairius rinkinius su senoviniais, gražiais, keistais, ekstravagantiškais daiktais, meno kūriniais, pagal galimybes buvo stengiamasi tokius rinkinius suformuoti. Daiktai būdavo igyjami ịvairiais būdais - perkami (kartais labai brangiai), mainomi, gaunami kaip dovanos. Rinkiniuose neretai būdavo ir iš vietos archeologinių paminklų (daugiausia pilkapių) iškastų radinių, daugiausia, žinoma, ginklų. Galbūt ir mūsų aptariama moneta ị kieno nors rankas pirmiausia pateko iškasus ar išarus kapą ar gyvenvietès kultūrinį sluoksnị, paskui kaip dovana ar prekė ji atsidūrè suinteresuoto asmens rankose, o šis jos neišsaugojo. Negalima pasakyti, kur toks paminklas galèjo būti pažeistas. Labiausiai tikètinas, žinoma, pajūris, bet, kaip rodo romėniškų monetų paplitimo mūsų krašte statistika, jų pasitaiko ir kitose vietose [13, 19 pav.; 14, Beilage 1].

Visgi moneta galètų turèti sąsajų, tiesa, taip pat grynai teorinių, su dviem šlako gabaliukais, rastais perkasų Nr. 35 ir Nr. 37 sluoksniuose su statybinèmis atliekomis. Atrodytų, kad tuo metu greta pilies, jos aplinkoje ar netoliese galejo būti pažeista senojo geležies amžiaus 
gyvenvietė ar kapas ir visa tai kartu su moliu ar žvyru kaip statybinės medžiagos pateko ị pilies kiemą. Tiesa, kad tokios sąsajos būtų labiau apčiuopiamos, reikètų detalių laboratorinių šlako tyrimų, tačiau ir tai vargu ar ką nors paaiškintų. Kita vertus, aplink Panemunès pili šiuo metu nežinoma jokio senojo geležies amžiaus archeologinio objekto. Bet tai nereiškia, kad tokio, tegu ir labai mažo, čia nebuvo ar negalèjo būti. Tiesą sakant, kol kas niekas rimtai nebande šioje vietoje ieškoti šio laikotarpio archeologijos paminklų. Kad tokia galimybè reali, rodo ne per toliausiai tyrinètas I a. Raudonėų kapinynas [5, 51-55] ir atvejis Jurbarke, kai netikètai buvo aptikta akmens amžiaus dirbinių ir pilkapio liekanų su III-IV a. kapais [2, 115-123]. Be to, netoli Panemunès esama paminklų, kuriuose rasta romėniškų monetų. Pirmiausia tai Žemoji Panemunè: čia piliakalnio tyrinėjimų metu rasta blogai išlikusi moneta su graikišku įrašu, ir Ramoniškių kapinynas, kuriame suardytų kapų vietose rastos 5 monetos $[14,46]$. Atskirai pažymėtina Kulautuva, čia suardytame vaiko kape rasta net 12 romėniškų monetų. Tai pirmas toks radinys Vidurio Lietuvos kapinynuose, be to, priskirtinas kapams su dideliu monetų skaičiumi [15, 40, 43]. Romėniškų monetų rasta ir prie Kauno buvusiame Veršvų kapinyne. Kiek kitaip atrodytų Seredžiaus ir Veliuonos lobiai, užkasti gerokai vèliau. Tačiau faktas, kad ir viename, ir kitame būta ne vienos roméniškos monetos, galètų būti nuoroda ị gretimoje aplinkoje buvusius atitinkamo laikotarpio paminklus. Visas šias vietoves jungia Nemunas, buvęs ir prekybine, ir migracijų, ir apskritai transporto arterija. Tačiau tai tik pasvarstymai, reali padètis yra kitokia. Visgi, kaip bebūtų, tokie atvejai priverčia suklusti, atidžiau pasižvalgyti po apylinkes - gal ką praleidome, nepastebėjome. Nèra jokios abejonès, kad Panemunès apylinkèse žmonès pradejo lankytis labai anksti. Ar jie buvo ịsikūrę ilgesniam laikui nuo pat pradžių - kitas klausimas. Vèlesnis laikas abejonių jau nekelia - greta stūkso apgriuvęs XIII-XIV a. pradžia datuojamas Kartupėnų piliakalnis, kuriame lokalizuojama Bisènès pilis [1, 224-225], kitoje Nemuno pusėje - Pakalniškių VIXIV a. senkapis su didžiuliu žirgų kapinynu [10, 79].

\section{IŠVADOS}

Panemunès pilies teritorijoje rastoji Gordiano III (238-244 m.) moneta yra varinis (?) antoninianas, kaldintas Romoje 243-244 metais. Romos imperijos monetų kataloge (RIC) ji atitinka Nr. 143. Pagal savo požymius (medžiaga, nominalas, gausumas) yra ịprastas radinys tarp kitų romėniškų monetų vadinamuosiuose barbarų kraštuose ir priklauso paskutinei žymesnei jų bangai ị šiuos kraštus. Lietuvos teritorijoje žinomų šio valdovo monetų atžvilgiu aptariamoji moneta priklausytų prie retesnių radinių.

Monetos radimas pilies (dvaro) teritorijoje šiuo metu yra pirmas toks atvejis panašių paminklų tyrinėjimo istorijoje ir nèra tiesiogiai susijęs su senojo geležies amžiaus (I-IV a.) paminklo tyrinejimais. Jos patekimas ị XVII-XVIII a. statybinių atliekų sluoksnị neabejotinai sietinas su arčiau ar toliau esamo ar buvusio tokio paminklo pažeidimu tuo metu. Sluoksnyje moneta galejo atsidurti tiesiogiai kartu su moliu ar žvyru, kaip statybinėmis medžiagomis, arba ją čia pametė mums nežinomas asmuo.

Gauta 20161027

Priimta 20161104

\section{Literatūra}

[1] BAUBONIS, Zenonas; ZABIELA, Gintautas. Lietuvos piliakalniai. Atlasas. T. 1. Vilnius, 2005.

[2] BAUBONIS, Zenonas; FEDIAJEVAS, Olegas. Pilkapyno vieta Jurbarko senamiestyje. Archeologiniai tyrinejimai Lietuvoje 2011 metais. Vilnius, 2012, p. 115-123. 
[3] BLIUJIENE, Audronè. Lietuvos archeologija. III tomas: Romėniškas ir tautų kraustymosi laikotarpiai. Klaipeda: Klaipèdos universiteto leidykla, 2013.

[4] GIRININKAS, Algirdas. Lietuvos archeologija. I tomas: Akmens amžius. Vilnius: Versus aureus, 2009.

[5] JOVAIŠA, Eugenijus. Raudonėnų kapinynas. Archeologiniai tyrinèjimai Lietuvoje 1974 ir 1975 metais. Vilnius, 1978, p. 51-55.

[6] JOVAIŠA, Eugenijus. Aisčiai. Raida. Vilnius: Lietuvos edukologijos universiteto leidykla, 2014.

[7] KAMPMANN, Ursula. Die Münzen der römischen Kaiserzeit. München: Battenberg / Gietl Verlag, 2004.

[8] KERŠYTĖ, Nastazija. Lietuvos muziejai iki 1940 metu. Lietuvos muzieju raida XVI-XX amžiaus ketvirtajame dešimtmetyje. Vilnius: Lietuvos nacionalinis muziejus, 2003.

[9] KULIKAUSKAS, Pranas; ZABIELA, Gintautas. Lietuvos archeologijos istorija (iki 1945 m.). Vilnius: Diemedžio leidykla, 1999.

[10] Lietuvos TSR archeologijos atlasas. III: I-XIII a. pilkapynai ir senkapiai. Vilnius: Mokslas, 1977.

[11] MALONAITIS, Arvydas; VAŠKEVIČIŪTĖ, Ilona; VITKŪNAS, Manvydas; JAKELAI-

TIS, Marius. Panemunès pilis ir jos aplinka. Archeologiniai tyrinejimai Lietuvoje 2011 metais. Vilnius, 2012, p. 186-199.

[12] MATTINGLY, Harold; SYDENHAM, Edward; SUTHERLAND, Carol; HUMPHREY, Vivian. The Roman Imperial Coinage. Vol. IV, part. III GORDIAN III - URANIUS. ANTONINUS. London: Spink and Son ltd., 1949 [žiūrèta 201610 23)]. Prieiga per internetą: http://scans.library.utoronto.ca/ pdf/3/12/romanimperial04pt3mattuoft/romanimperial04pt3mattuoft.pdf

[13] MICHELBERTAS, Mykolas. Prekybiniai ryšiai su Romos imperija. Lietuvos gyventoju prekybiniai ryšiai I-XIII a. Vilnius, 1972, p. 5-125.

[14] MICHELBERTAS, Mykolas. Corpus der Römischen Funde im Europäischen Barbaricum. Litauen. Vilnius, 2001, 68 s. 10 Tafel. Beilage 1.

[15] MICHELBERTAS, Mykolas. Ein Fund Römischer Münzen in Zentrallitauen. Archaeologia Lituana. T. 15. Vilnius: Vilniaus universiteto leidykla, 2014, p. 40-46.

[16] ŽALNIERIUS, Algirdas. Panemunès dvaro rūmų archeologiniai tyrinèjimai. Lietuvos archeologija, 2005, t. 27, p. 133-160.

[17] МИХЕЛЬБЕРТАС, Миколас. Два клада римских провинциальных монет из Западной Литвы. Нумизматика и эпиграфика. Т. 7. Москва: Наука, 1968, с. 68-71. 
ARVYDAS MALONAITIS

\title{
A Roman Coin from Panemunė Castle
}

\author{
Summary
}

The paper addresses the coin of Gordian III (reign 238-244 AD) found in the courtyard of Panemune Castle (Jurbarkas District Municipality, Pilis I Village, Skirsnemune Eldership) in the course of archaeological excavations carried out in 2011.

The coin in question is an antoninianus minted in Rome and dated 243-244; it corresponds to No. 143 in the Roman Imperial Coinage (RIC) catalogue. With respect to its descriptive attributes (material, denomination, abundance), it is a usual finding among other Roman coins in the so-called barbarian regions and belongs to their final more prominent wave to these regions. In the context of the coins of this ruler known on the territory of Lithuania, the coin is attributable to rarer findings.

The discovery of a coin in the area of a castle (manor) is so far the first case in the history of research of similar monuments and is not directly linked to the research of a monument dating back to the Late Iron Age (1st-4th c. AD). However, its access to the layer of construction debris of the 17th-18th century should definitely be linked to the damage of such a monument, which is/was located in closer or further proximity at that time. The coin could have found its way into that layer directly with clay or gravel as construction materials, or it was lost by a person not known to us.

Keywords: Panemunè Castle, a coin of Gordian III, antoninianus 